\title{
An Evaluation of Maize Contract Farming System in Sri Lanka: Adoption, Problems and Future Prospects
}

\author{
P. A. Jayamini Champika* and L.M Abeywickrama ${ }^{1}$ \\ Hector Kobbekaduwa Agrarian Research and Training Institute \\ Wijerama Mawatha \\ Sri Lanka.
}

\begin{abstract}
The constraints that hinder the growth of smallholder farmers have been attributed to lack of access to markets and technical expertise. Contract farming envisaged to facilitate the linkage between smallholder farmers and agribusiness firms who have built strong marketing channels. This paper attempted to examine the existing maize contract farming system in Anuradhapura district of Sri Lanka as a strategy of market stabilization through public-private partnership. Study applied principal component analysis to explain the factors affected in adoption. It was revealed that full-time farmers who have higher proportion of agricultural income, higher agricultural land holdings as well as agricultural experience and family labour participation were more prominent in adopting contract farming system. Moreover, statistically significant higher yield by maize contract farmers over non-contract farmers were achieved due to efficient input delivery mechanism of the buyer. Further, adopters earned about two times higher agricultural income than nonadopters. It revealed that following the whole contract farming model, vertically well integrated value chain management, mutual trust between farmers and buyers and existence of an assured market for buyers were the key factors for the success of the system. Inability to sell the whole harvest through contract farming system was the main obstacle faced by the contract farmers. It seemed that absence of a crop insurance scheme and unavailability of an authorized institution to regulate the contract farming process have hindered the diffusion of contract farming system throughout the country.
\end{abstract}

Keywords: Contract farming, Maize, Principal component analysis

\section{INTRODUCTION}

Over the past half-century, various attempts have been made to manage commodity price risks by stabilizing price volatility through market interventions. Key among these mechanisms were compensatory mechanisms, stabilization mechanisms and international commodity agreements. (Kang and Mahajan, 2006). With the poor performance of stabilization schemes, policy-makers began to pay more interest on market-based solutions for dealing with market uncertainty. (Central Bank of Sri Lanka, 2000a). The key advantages of market-based instruments over price stabilization schemes were providence of certainty of future revenues, comparatively low cost of implementation and shifting the risks to traders in industrialized countries who are willing to take the price risk (Varangis and Larson, 1996). The contact farming $(\mathrm{CF})$ has been implemented widely in developing countries as means to reduce risks related to price and quality and as a way

\footnotetext{
1 Faculty of Agriculture, University of Ruhuna, Mapalana, Sri Lanka

* Corresponding author: jayam1500@yahoo.com
} 
to reduce coordination costs within the food supply chain. In addition, $\mathrm{CF}$ is considered as a risk transferring mechanism, which enables small scale farmers to transfer market risks to global agribusiness firms (Woodend, 2003). Therefore, contract farming can possibly be considered as both risk reduction and risk transfer strategy, with reference to agriculture sector.

A forward sales contract (FSC) is an agreement between the seller and buyer to deliver a specified quantity of a commodity to the buyer at some time in the future for a specified price or in accordance with a specified pricing formula (Kang and Mahajan, 2006). A forward contract can be either extended to contract farming system by delivering inputs and extension service or confined to forward contract as it is (Eaton and Shepherd, 2001). However, the existing local and international literature suggest that long term viability and better execution of FSC is practiced only under contract farming system.

As an alternative to the conventional government intervention in agricultural marketing, the Central Bank of Sri Lanka (CBSL), introduced FSCs under the 'Govi Sahanaya' purchasing/pledge loan scheme in 1999. The CBSL had allocated Rs. 2650 million for farmers and Rs. 6500 million for buyers per year, under the pledge loan scheme (CBSL, 2000b). The private companies such as Plenty Foods Ltd, KST Company Ltd and Ceylon Agro Industries were the pioneers who joined the programme. After completion of ten year's direct involvement in 2009 by the CBSL, the system was left to its own operation, without further involvement of the CBSL. Since then, FSCs between farmers and buyers have altered to different forms and shapes and a few have developed to CF System.

The CF has been identified as one of the best solutions for price risk minimization related to small scale tomato famer in Haryana state, India (Dileep, Grover and Rai, 2002). Recent research conducted in India further revealed that yield and gross return obtained by the CFs were almost double that of non-CFs (Tuteja and Chandra, 2012). Further, Eaton, and Shepherd (2001) have identified the possibility of using contract agreements as collateral to arrange credit with a commercial bank in finding inputs. Moreover, vertical integration was also another expressed benefit of contract farming. However, researchers have identified number of common bottlenecks related to CF mechanism. Kumar et al. (2004) pointed out that, major problems faced by the contract farmers in India was irregular payments. In general, Singh (2000) studied the role of CF in agricultural diversification and identified problems related to poor co-ordination of activities, poor technical assistance, delayed payments, outright cheating in dealings and manipulation of norms by the firm. Baumann (2000) indicated that success of CF mostly depends on what alternative markets are available to the smallholders and the nature of their dependency on the producer.

Not many studies have been done on FSCs system or CF system in the context of Sri Lanka. Karunagoda et al. (2010) have conducted a research on factors affecting the adoption of forward sales contract of rice, maize and onion growers in Anuradhapura and Matale districts and reported low level of adoption of farmers' despite its favourable impact on reducing producer price risks. The analysis indicated that the land extent, participation in social activities and contact with village extension agent had positively influenced the adoption decision. Research further indicated that forward sales contracts have been able to provide a reasonable hedging mechanism to farm households who depend more on agriculture. With this background, present study focused on evaluating critical success and failure factors of existing CF system and to assess the factors affecting the adoption of $\mathrm{CF}$, in the selected area. Further, this research study is an attempt to fill the gaps in an effective future policy 
direction in the planning of CF as a strategy of market stabilization through public-private partnership (PPP).

\section{MATERIALS AND METHODS}

The study was conducted in Anuradhapura district in the North Central province of Sri Lanka (latitude $8.3^{\circ} \mathrm{N}$, longitude $80.5^{\circ} \mathrm{E}$ ). According to the agro-ecological classification, the whole district is classified as low country dry zone (DL1). The district receives rainfall mainly from Northeast monsoon, which begins in mid-September and extends up to midMarch in the following year (Punyawardena, 2004). Therefore, the major cultivation season in this area called Maha also begins in October and extends up to March. Anuradhapura district ranks top among the districts where maize cultivation is practiced in Sri Lanka. Of the national production of 218,989 mt of maize in 2012/2013 Maha season, 33\% was produced in Anuradhapura district. Further, Anuradhapura district accounted for $34 \%$ (26,557 ha) of total land extent devoted to maize cultivation in 2012/2013 Maha season (Department of Agriculture, 2013b).

A questionnaire survey was carried out to collect primary data. Multistage random sampling technique was adopted in selecting the sample for the survey. At the first stage, Anuradhapura district was selected purposively for its highest share in total area covered under contract farming. Five Divisional Secretariat Divisions (DSDs) of the district, namely Kekirawa, Thirappane, Galenbidunuwewa, Kahatagasdigiliya and Horowpotana were also selected purposively based on the prevalence of the long lasting CF system. The farmers who adopted the CF system were selected randomly from the farmers lists obtained through buyers. However, there were instances where a written agreement was not maintained between farmers and growers, even though the other steps of the CF were evident. Therefore, quantitative analysis of the sample was confined to the cases where a written $\mathrm{CF}$ agreement existed. A semi-structured, pre-tested questionnaire was administrated, either to the head of the household or to the decision maker who has taken the decision to join CF system.

The lists of independent growers were obtained from the respective divisional offices of the Department of Agrarian Development (DoAD), and the farmers were selected randomly from the list. The questionnaires were checked for the completeness and 75 farmers who adopted CF system and 50 individual growers were selected for the final analysis. Secondary data were obtained from the publications of Department of Agriculture, Sri Lanka, and Department of Census and Statistics, Sri Lanka. Study applied the chi-square test and student- $t$ test to compare the two groups of farmers, namely adopters and non-adopters.

Exploratory factor analysis is a widely utilized and applied statistical technique in social sciences. Of components models, the most popular one is the principal component analysis (PCA). The central concept of PCA is representation or summarization of multi dimensional data system using lesser dimensional space. Therefore, this study applied the PCA with varimax rotation to assess the underlying factors affected for adoption decision (Krishnan, 2010; Rummel 1970; Williams et al., 2012) 


\section{RESULTS AND DISCUSSION}

\section{Mode of operation of contractual system in study area}

As the survey results indicated, $89 \%$ of the cultivation in 2012 (by extent) was done in Maha season in upland, utilizing the rainfall. In these areas, contacted farmers were grouped into seventy to eighty member clusters and a leader farmer had been appointed for each cluster. Improved technology of cultivation is being supplied to the farmers in the form of regular field visits conducted by a trained field officer. All the inputs (seeds, fertilizer and agro chemical) were distributed through leader farmers at the onset of the cultivation season. Before the distribution of inputs, farmers had to sign the contractual agreement for the upcoming season, which included the detail of expected quality, quantity, price and date of the delivery. At the next step, farmers were required to pay a price advance (approximately $75 \%$ of the value of the inputs) to obtain the necessary inputs. Farmers were provided with on-call extension service, whenever necessary. During the harvesting, famers were provided with tarpaulin canvas to lessen the accumulation of moisture level during post-harvest handling. Farmers had to transport the product from their own fields to a temporary storage centre, normally established at leader famer's premises. At the storage centre, samples were tested for quality standards and payments were credited to the bank accounts of individual farmers within five working days.

\section{Supply chain and value chain management process adopted by the buyer}

A supply chain encompasses all the activities associated with the flow and transformation of goods from the raw material stage to the end user, as well as the associated information flows (Handfield and Nichols, 1999). Adding value to every possible link in the supply chain to offer maximum value to the consumers/end users is explained as value chain. As described in Fig. 1 the buyer has directly involved in the management of supply chain as well as the value chain from farm level to end user level. As the buyer has an assured market, they managed the supply chain and value chain in a vertically integrated manner at each and every link.

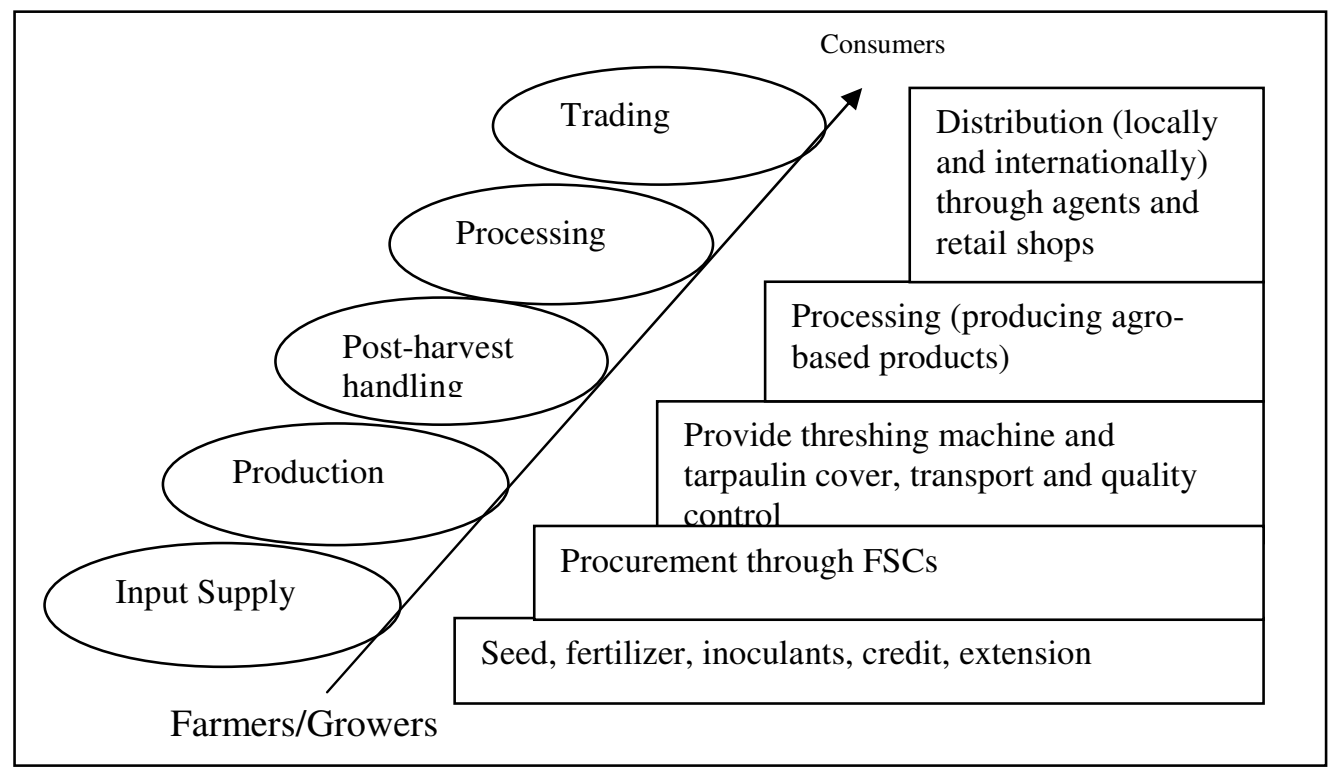

Fig. 1. Value chain management process adopted by the buyer 


\section{Comparison between contract farmers and independent growers, in Anuradhapura district}

The status of contract farmers was compared with non-contract farmers in the study area and the results indicated that there was a significant difference between adopters and nonadopters in relation to experience (in years), agricultural income (Rs./month), average yield (kg/ha) and extension services (Number of visits/season) (Table 1). Further, adopters had significantly higher formal education than non-adopters, as the reported chi-square value $(7.724, P<0.05)$ was significant at $5 \%$ level. Majority of the adopted farmers have attained secondary education while, majority of non-adopters had only primary education. As previous research indicated, accumulation of knowledge via education in human beings is an important factor of economic development (Kumar et al., 2004).

In relation to agricultural experience, there was a significant difference ( $t$ value $=4.448$, $P<0.05)$ between adopters and non-adopters, whereas adopters had more agricultural experience than non-adopters. Moreover, regarding agricultural income, a significant difference between adopters and non-adopters was observed as adopters (mean value Rs.50,453/month) have earned two times higher agricultural income than non-adopters (mean value Rs.20,617/month), $(t$ value $=7.201, P<0.05)$. Karunagoda et al. $(2010)$ indicated similar findings in a research conducted in Sri Lanka in 2006, related to three contracted crops namely onion, maize and paddy, where total land extent, farming experience and social participation have positively and significantly affected the adoption decision. Further, there was a significant difference between maize growers who adopted FSCs under CF system and independent maize growers in relation to average yield and received extension service (Number of visits /season). Of the sample, the contract farmers' yields ranged between 2,471 $\mathrm{kg} / \mathrm{ha}$ to $8,645 \mathrm{~kg} / \mathrm{ha}$, with an average yield of $6,355.4 \mathrm{~kg} / \mathrm{ha}$. This was significantly higher than the Anuradhapura district's average yield of 4,258 kg/ha, (Department of Agriculture, 2013a) as well as the non-contract framers' average maize yield of 5,239 kg/ha in the study area (Table 1). Tuteja and Chandra (2012) reported similar findings that, per hectare yield and gross return obtained by contract farmers were almost double that of non-contract farmers related to contract farming of tomato in Haryana state, India. Similar findings were obtained by Sriboonchitta and Wiboonpoongse (2008) related to contract farming system in Thailand and Haque (2000) and Singh (2000) related to contract farming practices of India.

Sri Lanka was almost self sufficient in maize in 2012, with the annual production of 225,739 $\mathrm{mt}$. The country's total maize requirement was $243,344 \mathrm{mt}$ in 2012 , which consisted of $215,344 \mathrm{mt}$ for animal feed production and 28,000 $\mathrm{mt}$ for human consumption. In 2005, the maize production within the country was only $22 \%$ of the country's requirement (Department of Agriculture,2012a and 2012b; Department of Animal Production and Health, 2012). It is believed that contact farming system has positively affected this achievement within a relatively short period of time (Source: key informant discussion with officers of CBSL). 
Table 1. Student $t$ - statistic for comparison of adopted farmers and independent growers in Anuradhapura district.

\begin{tabular}{lcccc}
\hline Variable & $\begin{array}{c}\text { CF } \\
\text { Mean } \\
\text { value }\end{array}$ & $\begin{array}{c}\text { NCF } \\
\text { Mean } \\
\text { value }\end{array}$ & $\begin{array}{c}\boldsymbol{t} \\
\text { statistics }\end{array}$ & $\begin{array}{c}\text { Sig; at } \\
\mathbf{5 \%}\end{array}$ \\
\hline Age (Yrs.) & 42.4 & 42.0 & 0.201 & 0.842 \\
$\begin{array}{l}\text { Experience (Yrs.) } \\
\text { Agricultural income of the family }\end{array}$ & 21.8 & 13.4 & 4.448 & $0.000^{*}$ \\
(Rs/month) & 50,453 & 20,617 & 7.201 & $0.000^{*}$ \\
$\begin{array}{l}\text { Non agricultural income of the family } \\
\text { (Rs/month) }\end{array}$ & 6,620 & 9,105 & 0.127 & 0.278 \\
Total up land extent (ha) & 2.39 & 2.23 & 0.518 & 0.606 \\
Land extent of the contracted crop (ha) & 1.25 & 1.40 & -1.099 & 0.276 \\
Availability of family labour (Full time) & 1 & 1.77 & -0.641 & -0.76 \\
Availability of family labour (Part time) & 0.49 & 0.38 & 0.673 & 0.502 \\
Average yield (kg/ha) & 6,355 & 5,239 & 4.631 & $0.000^{*}$ \\
Extension service (No. of visits /season) & 3.19 & 0.11 & 13.43 & $0.000^{*}$ \\
\hline
\end{tabular}

Source: Field survey, 2012

$* \mathrm{p}<0.05, \mathrm{CF}$ - contract farmer, NCF- non contract farmer

\section{Analysis of factors affecting the adoption of contract farming}

\section{Application of principal component analysis (PCA)}

Through PCA, it is attempted to explain the factors affecting the adoption of contract farming. The PCA enables summarization of total variance to few uncorrelated variables and visualize them in multi dimensional space. In order to assess whether factor analysis is appropriate for the variables, Bartlett's test of sphericity was carried out. The Bartlett's test of sphericity compares the correlation matrix with a matrix of zero correlations (technically called the identity matrix, which consists of all zeros except the 1's along the diagonal) (Williams et al., 2012). As the study received probability value of less than 0.05 for Bartlett's test of sphericity, it was concluded that the observed correlations are significant and valid factor analysis can be performed with the data.

Factor analysis techniques try to bundle up sub groups of variables together, based upon their correlations. By looking at the matrices, it can be concluded whether meaningful factor analysis is possible or not. As the statisticians suggest, if the correlation matrices has values more than 0.3 and less than 0.8, a meaningful factor analysis can be done (Robin, 2012) (Table 2). 
Table 2. Correlation matrices of the variables

\begin{tabular}{|c|c|c|c|c|c|c|c|c|}
\hline Variables & 1 & 2 & 3 & 4 & 5 & 6 & 7 & 8 \\
\hline 1. Age (Years) & 1.000 & & & & & & & \\
\hline $\begin{array}{l}\text { 2. Level of education } \\
\text { (levels) }\end{array}$ & -0.194 & 1.000 & & & & & & \\
\hline 3. Experience (Years) & $0.471^{*}$ & -0.001 & 1.000 & & & & & \\
\hline $\begin{array}{l}\text { 4. Agricultural income } \\
\text { (Rs/month) }\end{array}$ & 0.103 & 0.036 & $0.333^{*}$ & 1.000 & & & & \\
\hline $\begin{array}{l}\text { 5. Non agricultural } \\
\text { income (Rs/month) }\end{array}$ & -0.107 & 0.018 & -0.232 & -0.285 & 1.000 & & & \\
\hline $\begin{array}{l}\text { 6. Total upland extent } \\
\text { (ha) }\end{array}$ & 0.106 & 0.037 & 0.194 & $0.623 *$ & 0.181 & 1.000 & & \\
\hline $\begin{array}{l}\text { 7. Land extent of } \\
\text { contracted crop (ha) }\end{array}$ & -0.038 & -0.042 & -0.008 & $0.340 *$ & 0.096 & $0.609 *$ & 1.000 & \\
\hline $\begin{array}{l}\text { 8. Family labour } \\
\text { (Full time) }\end{array}$ & 0.061 & -0.079 & 0.192 & -0.151 & 0.025 & -0.015 & 0.146 & 1.000 \\
\hline
\end{tabular}

Table 3. The factor extraction values

\begin{tabular}{|c|c|c|c|c|c|c|}
\hline \multirow{2}{*}{ Construct } & \multicolumn{3}{|c|}{ Initial eigenvalues } & \multicolumn{3}{|c|}{$\begin{array}{c}\text { Extraction sums of squared } \\
\text { loadings }\end{array}$} \\
\hline & Total & $\begin{array}{c}\text { Variance } \\
\%\end{array}$ & $\underset{\%}{\text { Cumulative }}$ & Total & $\begin{array}{c}\text { Variance } \\
\%\end{array}$ & $\underset{\%}{\text { Cumulative }}$ \\
\hline 1 & 2.277 & 28.465 & 28.465 & 2.277 & 28.465 & 28.465 \\
\hline 2 & 1.527 & 19.091 & 47.556 & 1.527 & 19.091 & 47.556 \\
\hline 3 & 1.227 & 15.332 & 62.888 & 1.227 & 15.332 & 62.888 \\
\hline 4 & 0.982 & 12.275 & 75.163 & & & \\
\hline 5 & 0.856 & 10.698 & 85.861 & & & \\
\hline 6 & 0.520 & 6.498 & 92.359 & & & \\
\hline 7 & 0.345 & 4.308 & 96.667 & & & \\
\hline 8 & 0.267 & 3.333 & 100.000 & & & \\
\hline
\end{tabular}

Extraction method: Principal component analysis.

Total variance in all the observed variables equals the number of observed variables in the analysis (eight, in this case). The Initial eigen values present information about all the factors in the initial solution, while the extraction sums of squared loadings presents the same information only for the factors that were retained after extraction (Table 2). The eigen values present the amount of variance out of the total variance, explained by each of the factors. In this case, (Table 3) three factors are retained after the extraction (using the default cutoff criterion for extraction as eigenvalues over 1) and the extracted factors explained approximately $63 \%$ of the total variance in eight observed variables. 
The scree plot can be used as an alternative criterion for determining the number of factors to be retained after extraction (Williams et al., 2012). In this case, the scree plot also suggests that three factor solution is appropriate as the most prominent 'elbow' occurs at the fourth component, where three components positioned above the 'elbow' is selected (Fig. 1).Thus, both criteria (the 'eigenvalues over 1' and the 'elbow rule') suggested that extracting three factors is the most suitable to explain the total variance.

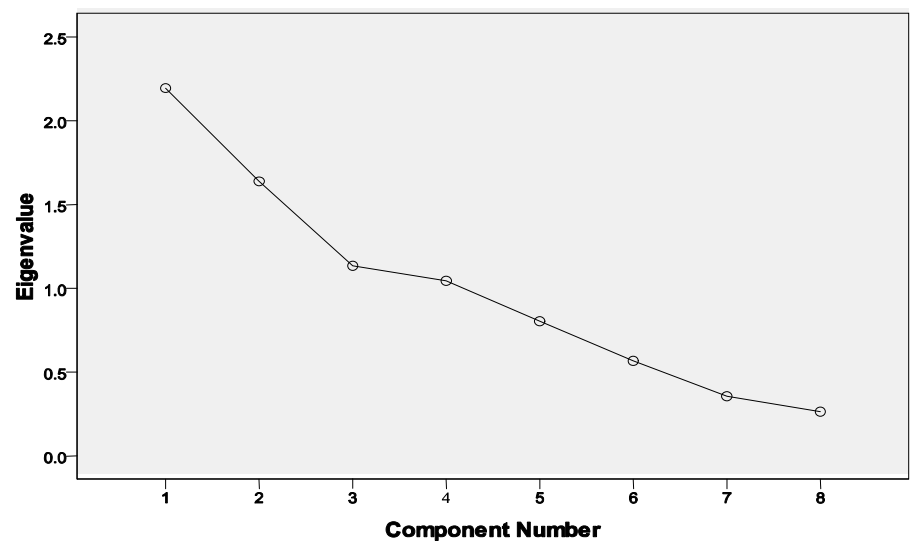

Fig. 1. The Scree plot diagram

The un-rotated factor loading values indicated comparatively high loading values (more than 0.50 ) for the constructs; experience, agricultural income, total land extent and land extent of contracted crop under component 1 . Only construct that indicated high loading values under component 2 was land extent of contracted crop. Under component 3, family labour (full time) showed comparatively high loading values. However, un-rotated component matrix showed high positive loading values for land extent of contracted crop under both components 1 and 2 . In order to improve the results with maximizing the loading of each variable on one of the extracted components, while minimizing the loading on all the other components, factor rotation was conducted.

As independence of the factors/components is assumed in this research, varimax rotation is applied and the results are presented in Table 4. The rotated component loading matrix indicated high loading values (as the loading values have been increased, cut off criteria is set as equal to or above 0.70) for the constructs agricultural income, total land extent and land extent of contracted crop, under component 1 . Further, high loading values for the constructs named as age and experience are obtained under component 2. Under component 3 , the only construct that showed a higher loading value was family labour (full time). The results of the rotated component matrix signified the un-related nature of components as each variable reported higher loadings on separate components. By observing rotated component matrix, it seemed that agricultural income, land extent of contracted crop and total land extent have come under one component which can be called as 'full time involvers in agriculture' Next, experience and age have come under another component, which can be called as 'more experience in agricultural activities'. Next, component 3 can be identified as 'family labour availability' for the agricultural activities. Therefore, it seemed that full time farmers with more experience and more family labour participation are more prominent in adopting CF system. 
Table 4. Un-rotated and rotated factor loadings

\begin{tabular}{|c|c|c|c|c|c|c|}
\hline \multirow[t]{2}{*}{ Constructs } & \multicolumn{3}{|c|}{$\begin{array}{c}\text { Un-rotated factor loadings } \\
\text { Component }\end{array}$} & \multicolumn{3}{|c|}{$\begin{array}{l}\text { Rotated factor } \\
\text { loadings } \\
\text { Component }\end{array}$} \\
\hline & 1 & 2 & 3 & 1 & 2 & 3 \\
\hline 1. Age & 0.359 & -0.690 & 0.123 & -0.033 & 0.700 & 0.360 \\
\hline 2. Level of education & -0.035 & 0.295 & -0.432 & 0.042 & -0.121 & -0.508 \\
\hline 3. Experience & 0.545 & -0.621 & -0.014 & 0.132 & 0.789 & 0.209 \\
\hline 4. Agric income & 0.812 & 0.155 & -0.267 & 0.709 & 0.405 & -0.298 \\
\hline $\begin{array}{l}\text { 5. Non Agricultural } \\
\text { income }\end{array}$ & -0.385 & 0.304 & 0.491 & -0.073 & -0.595 & 0.350 \\
\hline 6. Total land extent & 0.838 & 0.351 & 0.055 & 0.892 & 0.170 & -0.065 \\
\hline $\begin{array}{l}\text { 7. Land extent of } \\
\text { contracted crop }\end{array}$ & 0.580 & 0.529 & 0.466 & 0.845 & -0.233 & 0.255 \\
\hline $\begin{array}{l}\text { 8. Family labour } \\
\text { (Full time) }\end{array}$ & 0.054 & -0.242 & 0.702 & 0.051 & 0.011 & 0.743 \\
\hline
\end{tabular}

Extraction method: Principal component analysis.

Rotation method: Varimax with Kaiser normalization

\section{The price received by the contracted farmers}

As indicated by various studies in Asian region (Dileep, Grover and Rai, 2002) the contract farmers have received comparatively higher as well as stable prices than open market prices. Further, ability to sell crops elsewhere to get a higher price has become a critical factor which affects the long term viability of the contract (Baumann, 2000). This study revealed similar results that contracted prices of maize (Maha seasons' price) were higher than the producer prices of maize in relevant Maha seasons in Anuradhapura district throughout the period of ten years, except for the Maha season 2005/2006. Further, it was investigated whether there was a gap between agreed prices and paid prices in Maha seasons. The results revealed that, except in 2008/09 Maha season, a gap was observed between agreed price and paid price under CF system. Regarding all the instances where a gap was existed, buyer has actually paid a higher price than agreed price. Therefore, although it is not clearly mentioned under the CF agreement, it appeared that, the growers and buyers were agreed at minimum purchasing price at the beginning of the season, which allowed the buyer to increase the price in accordance with the open market price.

\section{Constrains faced by both contract and non-contract maize farmers}

As described in the Table 5, the major constraint faced by CFs (59.1\%) was, nonprocurement of the whole harvest. The average up land holding of contracted farmers was 2.39 ha, (Table 1) which ranged between 0.20 ha to 6.07 ha. However, buyers have set a ceiling of 0.80 ha land area for a farmer, once they signed the contract agreement. Through setting up this upper limit, buyers have attempted to fulfil two objectives; one is to minimize the risk of obtaining quality produce in the event of climatic hazards and at the same time to maximize the opportunity to join CF system with a large number of small scale farmers. However, in farmers' point of view, procurement of part of the produce has caused many problems to the contract farmers. They had to sell rest of the harvest in the open market and confront all the risk and uncertainties that individual growers face. Further, the banks were somewhat reluctant to accept the contractual agreement as collateral as they were buying 
only part of the harvest. Therefore, difficulty in obtaining formal credit facilities $(47.7 \%)$ was the second most important bottleneck, which farmers have faced. Even though contractual agreement had affected positively in obtaining formal credits in other developing countries (Eaton and Shepherd, 2001), it has not impacted much in Sri Lankan context. Farmers were of the opinion that, if more buyers joined the CF system, especially companies who are engaged with animal food production, they would be able to sell the whole harvest including the low quality produce. As it was witnessed, increasing seed cost (43.7\%) was beyond the control of the buyer or the government of Sri Lanka as the cultivated hybrid variety pacific 999 is solely imported. As per the sector specialists, the only viable solution was to encourage local seed production.

Regarding non-contract farmers, the most critical problem they faced $(61.2 \%)$ was the uncertainty of obtaining reasonable price in the next season. Majority of non-contract farmers $(67 \%)$ have sold their produce to the collectors who generally come to their door step. Farmers had experienced various kinds of cheatings when transacting with these mobile collectors hence the most prominent complaint was using of fraudulent balances in weighing. Contracted and non-contracted farmers (36.3\% and $35.1 \%$, respectively) mentioned absence of crop insurance scheme as the main constraint that they faced. With the increasing frequency and severity of unpredictable climatic extremes, farmers stressed that they are in need of a security for their investment.

Table 5. Constraints faced by both contracted and non-contracted maize farmers in Anuradhapura district

\begin{tabular}{lcc}
\hline Constrains Faced by Farmers & $\begin{array}{c}\text { Contract Farmers } \\
(\mathbf{\%})\end{array}$ & $\begin{array}{c}\text { Non-Contract } \\
\text { farmers (\%) }\end{array}$ \\
\hline Inability to sell whole harvest to the buyer & 59.1 & 0 \\
Ever increasing input cost & 43.7 & 28.4 \\
Difficulty in obtaining formal credit facilities & 47.7 & 36.5 \\
Lack of a crop insurance scheme & 36.3 & 35.1 \\
$\begin{array}{l}\text { Difficult to meet the quality standard in the } \\
\text { event of climatic hazards }\end{array}$ & 36.0 & 5.2 \\
$\begin{array}{l}\text { Uncertainty of obtaining reasonable price in } \\
\text { the next season }\end{array}$ & 14.7 & 61.2 \\
$\begin{array}{l}\text { Receiving of low price due to influence of } \\
\text { intermediaries }\end{array}$ & 6.3 & 31.4 \\
Lack of storage facilities & & \\
\hline
\end{tabular}

Source: Field survey, 2012

Note: As this is a multi-response question, sum of the percentages of each column exceeds $100 \%$.

\section{CONCLUSIONS}

Principal component analysis revealed that full-time farmers who have higher proportion of agricultural income, higher agricultural land holdings as well as agricultural experience and family labour participation were more prominent in adopting contract farming system. Besides that, the interaction of package of services provided by the buyers, such as input and extension had positively and significantly affected the productivity (yield/ha) achieved by the contract farmers. Further, contract farmers have been able to fetch a higher price than the open market price, in most of the instances. Among the constraints faced by the contract farmers, price instability was not a significant problem, whereas it was the most critical 
problem faced by the non-contract farmers. Therefore, it appears that in the case of maize, contract farming system has been effective as a market based instrument of price stabilization in Sri Lanka. As the CF agreement is developed based on mutual understanding of farmers and buyers, development of specific legislation and guidelines for contract farming practices in Sri Lanka is a prerequisite for further diffusion of the system.

\section{ACKNOWLEDGEMENT}

The author wish to acknowledge the financial and technical support of the Hector Kobbekaduwa Agrarian Research and Training Institute (HARTI), Colombo, Sri Lanka, in the process of primary data collection.

\section{REFERENCES}

Baumann, P. (2000). Equity and efficiency in contract farming schemes: The experience of agricultural tree crops. Working paper 139, [on line]. [Accessed on 12.08.2012]. Available at http://www.odi.org.uk/resources/2022.pdf.

Central Bank of Sri Lanka. (2000a). Annual Report 1999. Janadhipathi Mawatha, Colombo 01, Sri Lanka.

Central Bank of Sri Lanka. (2000b). 'Govisahanaya scheme'. Central Bank of Sri Lanka, Janadhipathi Mawatha, Colombo 01, Sri Lanka.

Department of Agriculture. (2012a). Crop forecast 2011/12 Maha-final. Socio Economic and Planning Centre, Department of Agriculture, Peradeniya, Sri Lanka.

Department of Agriculture. (2012b). Crop forecast 2012 Yala-final. Socio Economic and Planning Centre, Department of Agriculture, Peradeniya, Sri Lanka.

Department of Agriculture. (2013a). Cost of cultivation of agricultural crops 2011/12 Maha. Socio Economic and Planning Centre, Department of Agriculture, Peradeniya, Sri Lanka. Department of Agriculture. (2013b). Crop forecast 2012/2013 Maha-final. Socio-economic and planning Centre, Department of Agriculture, Peradeniya, Sri Lanka.

Department of Animal Production and Health. (2012). Livestock Statistical Bulletin. 5(1): Department of Animal production and Health, Peradeniya, Sri Lanka.

Dileep, B.K., Grover, R.K. and Rai, K.N. (2002). Contract farming in tomato; An economic analysis. Indian Journal of Agricultural Economics. 57(2), 197 - 210.

Eaton, C. and Shepherd, A.W. (2001). A guide; contract farming partnership for growth. Agricultural Service Bulletin, Food and Agriculture Organization, Rome.

Handfield, B.R. and Nichols, L.E. (1999). Introduction to supply chain management. Prentice Hall, New Jersey, United States.

Haque, T. (2000). Contractual arrangements in land and labour markets in rural India. Indian Journal of Agricultural Economics. 55(3), 233 - 252. 
Kang, M.G. and Mahajan, N. (2006). An introduction to market-based instruments for agricultural price risk management, Agricultural management and marketing and finance working document. Food and Agriculture Organization, Rome.

Karunagoda, K.S. Karunagoda, K.P.N.S. Gunawardhane, H.P. Senanayake, S.P.R.P. and Wickramasinghe, Y.M. (2010). Factors affecting the adoption of agricultural forward sales contracts in Sri Lanka: Journal of multidisciplinary studies. 1(1), 17 - 24.

Krishnan,V. (2010). Constructing an area-based socioeconomic index: A principal components analysis approach. Early Child Development Mapping Project (ECMap). [on line].[Accessed on 17.08.2013]. Available at http://www.cup.ualberta.ca/wpcontent/uploads/2013/04/ SEICUPWebsite_10 April13.pdf

Kumar, S. Chand, P. Dabas, J.P.S. and Singh,H. (2004). Characteristics and determinants of Contract design of Wheat Seed farming in India: Indian journal of Agricultural Economics. 65(4), $621-638$.

Punyawardena, B.V.R. (2004).Technical report on the characterization of the agro-ecological context in which Farm Animal Genetic Resources (FAnGR) are found: Sri Lanka.[on line]. [Accessed on 01.02.2014]. Available at http://www.ruh.ac.lk/research/academic_sessions/2006_mergepdf/102-117.pdf.

Rummel, R.J. (1970). Applied factor analysis. Evanston, IL, Northwestern University Press. Illinois, USA.

Robin,B. (2012). An introduction to principal component analysis and factor analysis using SPSS 19 and $\mathrm{R}$ [on line]. [Accessed on 23.05.2013]. Available at http://www.floppybunny.org/robin/web/virtualclassroom/stats/statistics2/pca1.pdf.

Singh, S. (2000). Contract farming for agricultural diversification in the Indian Punjab: A study of performance and problems. Indian Journal of Agricultural Economics. 56(3), 283 294.

Sriboonchitta, S. and Wiboonpoongse, A. (2008). Overview of contract farming in Thailand, Lessons learned. Asian Development Bank Discussion Paper No.112, Tokyo, Japan.

Tuteja, U. and Chandra, S. (2012). Impact of emerging marketing channels in agricultural marketing: Benefits to producer, seller and marketing costs and margins of agricultural commodities in Haryana [on line]. [Accessed on 07.24.2014]. Available at http://www.du.ac.in/du/uploads/Academics/centres_institutes/Agricultural_Eco/14.2012Marketi\%20channels\%20Haryana\%20Usha\%20Tuteja.pdf.

Varangis, P. and Larson, D. (1996). Dealing with commodity price uncertainty. World Bank Working Paper No.1667. Washington DC, USA.

Williams, B. Brown,T. and Onsman, A. (2012). Exploratory factor analysis: A five-step guide for novices Australasian Journal of Para medicine. 8(3): [on line]. [Accessed on 22.10.2013]. Available at http://ro.ecu.edu.au/jephc/vol8/iss3/1.

Woodend, J.J. (2003). Potential of contract farming as a mechanism for the commercialisation of smallholder agriculture: The Zimbabwe case study [on line]. [Accessed on 08.10.2013]. Available at ftp://193.43.36.93/docrep/fao/010/ah925e/ah925e00.pdf. 